\title{
Ensuring adaptation to climate change does not increase health risks from the built environment
}

\author{
Kelvin Walls
}

Correspondence: buildcode@xtra.co.nz

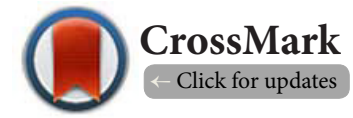

Director, Building Code Consultants Ltd, P O Box 99-613, Newmarket Auckland, 1149, New Zealand.

\begin{abstract}
Adaptation to climate change is taking place and there is a need to ensure that it escalates unabated to provide support for and mitigate the adverse effects of the present world population. However, the built environment is changing at an exponential rate in all aspects such as complexity, coverage over the earth's surface and in accommodating a burgeoning world population. Natural disasters such as flooding, inundation, drought, hot days and fire continue to occur, some of which may be attributed to or exacerbated by climate change, impact on the built environment. Apart from direct mortality of many people and resulting morbidity affecting many more people, the vulnerabilities of the built environment in providing shelter, warmth, comfort and services to people are exposed and challenged with each successive disaster event. While we strive to improve our processes and implement new technologies to cope and improve quality of life under a climate change regime, we must also be sufficiently circumspect to avoid adverse and unintended consequences, which may include eye diseases from modern artificial lighting, increased radon exposure from air-tight buildings, Legionella infections from air conditioning systems, dengue fever due to increasing numbers of on-site rain water tanks and others.
\end{abstract}

Keywords: Adaptation to climate change, built environment, inundation, burgeoning world population, unintended consequences, drought, natural disasters, flooding, hot days

\section{Introduction}

Climate change is a reality [1]. There is little doubt, based on the evidence, that climate change is occurring and it is likely to lead to floods, storms, hurricanes, cyclones, heat waves and drought $[2,3]$.

Buildings are a significant contributor to global climate change [2]. In general terms, the construction and use of buildings consume up to $50 \%$ of all energy consumption and $50 \%$ of all material taken from nature. They also produce $50 \%$ of all waste and $50 \%$ of all CFC and HCFC production [4]. More specifically, in 2004, the building sector contributed an estimated $3 \mathrm{Gt} / \mathrm{yr}$ of $\mathrm{CO}_{2}$ emissions to the atmosphere [5] and approximately $43 \%$ of US $\mathrm{CO}_{2}$ emissions from all types of buildings [6-8]. U.S. $\mathrm{CO}_{2}$ buildings emissions approximately equal the combined carbon emissions of Japan, France, and the United Kingdom. The total 2005 methane emissions for all US buildings was $38.9 \%$ of all US methane emissions [8]. Buildings are therefore major sources of pollutants that lead to climate change.

Paradoxically, even an energy-efficient house is not sustain- able in a strict sense. Every building covers ground that would otherwise be organically productive or useful in some other way, thereby making it functionally sterile. Every building reduces the area of the earth that is capable of keeping the earth in balance due to the natural interactions between soil, sun and water [9]. All human activities produce green-house gases that are said to be detrimental to the functioning of the earth from the point of view of human habitation.

Humans are the only animals that create waste. Buildings and associated infrastructure provide human habitat. In contrast to what natural undeveloped land does, buildings fail on all other aspects of life principles. Some of these other principles are to create clean air and water, store water, create its own food, create rich soil, use and store solar energy, provide wildlife habitat, moderate climate and weather and consume its own waste.

However, buildings are an integral component of the environment in which we live, and thus an important determinant of human health. While good building design supports our health and wellbeing $[2,10]$, poor building design is associated with a wide range of health conditions, including respiratory 
infections, asthma, lead poisoning, injuries, and poor mental health [10-12].

Thus, in addition to being important environments for climate change adaptation strategies, buildings' significant contribution to greenhouse gas emissions provide an important opportunity for climate change mitigation $[2,5]$. The challenge is to ensure that such strategies do not result in unintended adverse health effects [13].

Sustainable development and the health of populations depend on each other - they are indivisible at a global level $[14,15]$. But is sustainable development really possible? While most of us learn from direct experience with feedback - that is facing the consequences of our actions, this does not apply to the notion of sustainability as we are usually unable to observe the consequences of our actions due to gradual environmental change over time. Sometimes, however, we are able to make those observations but forget what existed several decades ago. Degradation to the environment is so gradual that most people are not able to discern or forget changes over time. Younger people just accept the status quo of the environment that 'it has always been like that'.

What is the link between sustainable building as an ethical issue and building design and construction as pragmatic activities? The main mitigating factor with new building or infrastructure development is that they remain relevant and useful for a maximum period of time and that they are designed to be capable of minimal modification in dealing with changing user needs during the life of the building or infrastructure development [16].

Given that each mitigating action still continues to have incremental adverse results for the long-term sustainability of the earth may leave us all in a slight dilemma. The stakes are now higher that we are adapting to climate change and there is a need to ensure that this does not result in further unplanned adverse health outcomes. So while our whole built environment and way of life are affecting climate change, conversely climate change itself is influencing how we are mitigating its effects and reshaping our cities [17].

In order to mitigate increases in morbidity and mortality due to various adverse effects caused by climate change (in Australia) there should be changes to building codes and urban design [18]. This is happening throughout the developed world, but will it be enough given our assumption that all buildings and infrastructure are inherently unsustainable?

\section{Methods}

\section{Challenges from climate change relating to the built environment \\ Flooding/inundation}

The damaging effects of flooding are complex as they can affect different aspects of the built environment in different ways. All infrastructure including buildings, gas, petroleum, or geothermal energy pipelines, electricity supply systems, water supplies, sewage treatment and disposal systems, roads, bridges, rail lines, airports and telecommunications systems are designed against a specific storm probability based on present design criteria for specific regions. All aspects of the built environment (infrastructure) need to be designed and constructed (or modified) to deal with likely increased flooding in the future. The "health" of infrastructure has direct or indirect effects on acute or chronic health of people who are served by those services.

Floods are the most common natural disaster worldwide [19]. Flooding has been a perpetual problem since mankind has congregated in towns and it presently occurs constantly with scant reporting on such events in the international media. For instance a report in August 2013 of 110 people killed and a further 300,000 affected by heavy monsoon rains and flooding across Pakistan [20] was apparently picked up by few media outlets and the situation can only worsen with a burgeoning world population having to densify development in increasingly marginal land.

Flooding is presently the most common natural disaster and is the most expensive in terms of economic damage in Europe. The future scenario for most of Europe is wetter conditions during the winter season, more frequent floods and more intense summer storms. Apart from drowning and injuries, floods lead to water-borne infections, acute or chronic effects of exposure to chemical pollutants released into flood waters, vector-borne diseases and food shortages [21].

Climate change is likely to be a factor in increased riverine, pluvial and coastal flooding [21] and is likely to influence flooding through changes in rainfall, temperature, sea level and river channel processes exacerbating existing effects on infrastructure [22]. Climate change is a reality and although necessary, adaptation actions can create unintended impacts on other natural and social systems and the physical and ecological environment [1].

The economic costs of coastal flooding alone are set to amount to $\$ 1$ trillion annually by the year 2050 if no mitigating steps are taken [23].

Flooding is likely to be a factor leading to an increase in morbidity and mortality due to the effects of climate change in Australia [18]. The actual effects of increased flooding are not well known and the health effects associated with being flooded in the UK has been the subject of little research [21], despite the fact that it has been significantly affected by past severe flood events. While some sea defences have been built, research into flood disaster mitigation has lagged behind in the UK [21].

Appropriate land-use planning is required to ensure that structures are located away from flood-prone areas and flood plains. This is problematic, as many highly populated cities are situated in flood-prone areas or in flood plains, such as Bangladesh, where about 15,000 people die each year in flood disasters [21]. It was the scene of eight of the ten costliest disasters during the $20^{\text {th }}$ century [24]. Bangladesh is one of the poorest and most flood-prone countries in the world 
who face the highest risk of flooding but are the least well prepared to deal with it [25], although it has developed some effective mitigation strategies [26]. It is also expected that over $50 \%$ of the population will be adversely affected with a $4^{\circ} \mathrm{C}$ increase in temperature [27]. The progression of flood disasters in that country is expected to increase dramatically with climate change and rising sea level. Rapid urbanization has led to the demise of the wetlands around Dhaka, the capital [28]. This has the effect of removing a flood detention area which mitigates peak flood flows.

Nicholls et al., 2008 examined the exposure of 136 of the world's large port cities to coastal flooding due to storm surge and damage due to high winds with a comparison of effects by the 2070s under a climate change regime [29]. It focused on the huge financial cost estimates of extreme water levels relative to a baseline represented by current exposure to 1 in 100 year storm events. The dominant drivers of increased flood exposure are said to be population growth/ urbanisation, climate change and subsidence-both natural and anthropogenic (caused by groundwater extraction and drainage). The complexities and vast variations that could result would no doubt place predictions of human health in the realm of speculation.

Although deforestation contributes to climate change $[30,31]$, but which is not discussed in this article, apart from coastal inundation, flooding is exacerbated by deforestation. The less vegetated landscape has less rain water absorption capacity and intensified stormwater runoff into rivers and other lowland areas, leading to higher flood levels. Other adverse consequences of deforestation include species loss, carbon emissions, disruption of the water cycle, soil erosion and reduced life quality by soil erosion into bodies of water [32]

Increasing urbanization alone leads to additional flooding as previously vegetated or cropped farmland is displaced with impervious surfaces of roads, buildings and pavement and this leads to intensified stormwater runoff, diminished groundwater recharge and increased channel and river erosion [33].

A secondary outcome of cyclones and flooding can be landslides [34], which on their own can cause considerable loss of life and disruption to communities.

\section{Drought}

Droughts lead to a fall in crop production due to inadequate rainfall causing farmers to struggle to maintain their standard of living. The selling of livestock in order to earn some money (albeit at lower prices) and to reduce grazing density on impoverished grass cover becomes a common short-term action. The lowest value animals such as sheep and goats are usually first to be sold. In extended periods of drought farmers are then forced to transport and draft animals, such as oxen and donkeys, and then breeding stock which constitute the basis of the household's wealth [35]. The flow-on effect can be immense. Changes in the distribution of wealth usually accompany drought. "The worst drought in decades", in the first few months of 2013 led to annual real GDP fall of around $0.6 \%$ in New Zealand [36]; a country of moderate climes and usually adequate to plentiful rainfall, making it a dominant agricultural producer. The drought covered much of the country and was confirmed as the most serious drought in around 70 years [37]. This was considered to be a one-off event, but too many more such events, we suggest, would cause New Zealand considerable harm.

Extreme weather events, attributed to climate change, are presently wreaking havoc in Australia-heatwaves, floods, bushfires and cyclones are all killers, also leading to "infectious disease risks, mental depression and community destruction" [38]. Droughts may also lead to famine, malnutrition, poverty, poor public health practices, contamination of existing water supplies, social strife and with increasing potential for conflict over water resources [19].

\section{Hot days/fire}

A 2003 heatwave in Europe caused an estimated 30,000 deaths (of mostly elderly persons) [24]. The World Health Organisation (WHO) estimates that excess mortality from extreme heat events in Europe is likely to range between $7.6 \%$ and $33.6 \%$ in nine European cities [39]. They cited that most homes have an indoor temperature of $17-31^{\circ} \mathrm{C}$ and that humans cannot live comfortably outside this range [39] when heat waves by definition, in Adelaide, for example, are five consecutive days with the maximum temperature of at least $35^{\circ} \mathrm{C}$ or three consecutive days with at least $40^{\circ} \mathrm{C}[40]$.

Australia presently suffers from frequent heatwaves and they are the most common natural hazards experienced in Australia [40]. When Melbourne experienced three consecutive days of at least $43^{\circ} \mathrm{C}$ in January 2009 an increased estimated death incidence from 606 to 980 (or a $62 \%$ increase) occurred [38]. The following month Victoria was faced with calamitous bush fires with many of them registering heat above $1,200^{\circ} \mathrm{C}$ and wind speeds in excess of $120 \mathrm{~km} / \mathrm{hour}$ [41] when 173 people died [40]. The Victoria Government immediately introduced a new residential building standard [41] recognising that severe bushfires are part of the future. "Australia has special reason to be alarmed" at climate change [42].

With a gradual rise of global temperatures leading to an increase in the severity, duration and frequency of extreme heat waves, heat stress and direct thermal injury are expected to affect people in parts of the US [43], Australia and many other countries. Most vulnerable to the adverse health effects are likely to include the elderly, those with specific underlying health conditions and those without air conditioning $[43,44]$, thereby affecting the poor [44].

The urban heat island affect is also expected to play a greater part in heat stress and adverse health effects $[13,18,43-46]$. Cities are almost always warmer than surrounding rural areas, especially in city centres with higher building densities - with a differential of $5^{\circ} \mathrm{C}$ with London [13] - by sometimes more than $10^{\circ} \mathrm{C}$ warmer than surrounding rural areas [44]. 
Kelvin Walls, Journal of Environmental Engineering \& Ecological Science 2016,

http://www.hoajonline.com/journals/pdf/2050-1323-5-1.pdf

doi: $10.7243 / 2050-1323-5-1$

\section{Earthquakes}

Climate change related risks are place-specific [47] and "the power of place still holds the vast majority of us in its thrall" and "the overwhelming majority will die very near the cabin in which they were born" [24]. This adherence to tradition is likely to hinder adaptation to environmental change $[\mathbf{2 4 , 4 8}$. These "cabins" are in areas, cities, megacities and countries that arose despite the inherent risks of being exposed to high earthquake risk (e.g., Turkey, Iran, Pakistan, Japan and Mexico) or at risk of flooding (e.g., Bangladesh, New York and Shanghai). The number of their (future) megacities and their individual exposures puts them seriously at risk of very high death rates in future seismic events [49]. Bangladesh is in the unenviable position of being at severe risk of flooding and cyclones as well as earthquakes; the latter of which are due to its high population density, poor enforcement of building codes, a large number of earthquake-prone buildings and over-stretched infrastructure of roads, electricity and water supplies [26].

Earthquakes can trigger landslides as well as damage to dams and reservoirs needed for drought and flood protection [50] which (earthquakes) on their own can cause considerable loss of life and disruption to communities (as with cyclones and flooding). This has occurred several times in southeast China due to strong earthquakes, steep topography and a fragile geological environment, with resultant loss of life sometimes exceeding that of the main earthquake event itself [51]. This would be exacerbated by the fact that there are many relatively dense populations of people in towns and cities in steep and rugged mountainous areas in China.

Populations located over tectonic plate activity zones face a high risk of earthquake-related morbidity and mortality, and they continue to grow in many of these high risk zones, facing even greater risk [52,53]. In the 20 years 1985-2005 earthquakes caused more than a million deaths worldwide with almost half that number in China. Similar rapid urbanisation in other seismically active areas of the world is likely to lead to an increase in deaths and injuries in future $[\mathbf{5 4 , 5 5}$.

Major earthquakes tend to produce devastating effects in relation to injuries and mortality of a unique type. They devastate the local curative medical capacity and interrupt medical supply chains along with destroying roads, bridges and other infrastructure. For those with chronic disorders such as diabetes, heart disease and asthma their condition may make worse, after an earthquake, loss of medications and medical equipment and supplies [55]. For instance in the 2001 Gujarat, India earthquake there were two district hospitals and 1,200 health clinics damaged or destroyed. For many survivors there are direct social and psychological impacts along with economic consequences associated with rehabilitation [56]. Psychological problems also affect rescue and medical teams [57].

Earthquakes often affect populous urban areas with poor structural standards and high non-compliance with existing codes [56] and thousands of children died in collapsed schools in the Wenchuan earthquake in China in 2008 [58].

The unpredictable nature and severity of earthquakes, however, mean that there may be similar consequences also in some developed countries which are reputed to have higher building standards. During the Loma Prieta, California, earthquake in 1989 the Watsonville Community Hospital was damaged, lost water supply and had damaged generators and passenger lift function, and other hospitals were damaged. There were 63 fatalities and 3757 people were injured [59].

In the case of the February 2011 earthquake in Christchurch, New Zealand in which there were 182 fatalities and 6,659 people injured, the only regional acute hospital was compromised by earthquake damage, but continued functioning, with complete loss of electrical power, and stairwell and lift access problems. Emergency diesel powered generators activated within a few seconds of the power outage but one later failed due to shaking having disturbed sump sludge inside diesel tanks. Telephone communications became overloaded causing difficulties for the emergency department [59].

Hospitals were damaged in the Loma Prieta 1989, Gurarat 2001, Wenchuan 2008 [58] and Christchurch 2011 earthquake events despite the fact that in most jurisdictions hospitals for several decades have normally rated amongst the highest "importance" category for seismic design purposes $[\mathbf{6 0 0 , 6 1 ]}$. Hospitals are often affected in earthquakes [62] -simultaneously an internal and external disaster: "Emergency plans for earthquakes must take into account the fact that the same shaking that just inflicted an internal disaster on your facility also caused an external disaster in your community or region" [63]. The paradox is that hospitals are often among the most vulnerable structures while forming key elements of critical infrastructure [62]. History of damage to hospitals and resulting injuries and fatalities in past earthquakes should be reviewed and used to mitigate damage to hospitals in future earthquakes.

Crisis-driven law is as a result of catastrophes catalysing regulation [64]. The Wenchuan earthquake 2009 had a modernising impact on building codes in China [58] and the Canterbury earthquakes in 2010 and 2011 evoked an immediate response by the government of New Zealand.

Major earthquake events leading to large loss of life and injuries will continue to occur throughout the world which will tend to exacerbate the effects on a burgeoning population that is becoming more intensely concentrated in urban areas and mega-cities. Traditional crisis-driven change in building codes and medical response techniques will be inadequate to provide the necessary future assistance in earthquake disasters especially in those countries that presently show little regard for ensuring that current earthquake design and construction knowledge is applied to buildings. These are usually vulnerable societies with weak governments upon which the hardships of climate change are likely to add to the burden of poverty and human insecurity [65]. There is evidence 
to show that morbidity and mortality from environmental threats is already happening to marginalized populations [66].

\section{Results \\ Built environment response strategies and their asso- ciated challenges to health-Climate change mitigation opportunities \\ Fluorescent lights}

Eye disease could increase as a result of the global trend towards replacing incandescent globes with energy-efficient fluorescent lighting. With climate change, reducing our greenhouse gas emissions is important. One way to do this is to phase out incandescent lighting in favour of more energyefficient lighting.

This shift has already taken place in Australia and countries of the European Union $[\mathbf{6 7}, \mathbf{6 8}]$. In the United States, federal law stipulates that incandescent lights be phased out by 2014 [69]. In Australia, this change in lighting type has been estimated to reduce greenhouse gas emissions by approximately 28 million tons between 2008 and 2020. Thus a global move toward fluorescent lighting in the home will lead to significant reductions in greenhouse gases [70].

The types of energy-efficient lighting with which incandescent lights are being replaced are high-intensity discharge (HID) lamps, light-emitting diodes (LEDs), and fluorescent lighting, including the popular compact fluorescent lamps (CFLs). These light sources are all more efficient than the incandescent lamp. HID lamps produce intense light in a small area. They are less energy efficient than fluorescent lights, but are used widely for lighting large areas such as streets and sports facilities. LEDs are energy efficient but not as bright, stable, or cheap as fluorescent lights [71].

However of all these lighting types, fluorescent lighting is considered most energy-efficient and also produces light most appropriate for working under. CFLs use $75 \%$ less energy than do incandescent lamps [72]. As a result of the popularity of fluorescent lighting, many people are now exposed to artificial sources of UV radiation emitted from these lights [71]. More recent trends of using LED lighting may also expose occupants to harmful UV radiation, but this needs further research.

There is a general public awareness that UV radiation from the sun can damage the eye. For example, most people are aware of the importance of not looking directly at the sun, and operators of arc welders know to wear protective goggles. Less attention has been paid to the potentially damaging effects of UV radiation people are exposed to indoors, in particular from fluorescent lighting, a significant source of UV light [71].

The safe range of light, to avoid exposing the eye to potentially damaging UV light, is approximately 2000 to $3500 \mathrm{~K}$ and greater than $500 \mathrm{~nm}$. UV wavelengths less than $500 \mathrm{~nm}$ (and certainly less than $380 \mathrm{~nm}$ ) are capable of irreparable damage to the eye. Unfortunately, some fluorescent lights currently fall outside this safe range [71].
CFLs vary in terms of color temperature, and there are variations and inconsistencies among manufacturers. The fluorescent lighting used indoors, particularly in commercial settings, is often in the form of cool-white tubes with a color temperature of $4000 \mathrm{~K}$ or greater. The warmer CFLs, which are usually less than $3500 \mathrm{~K}$, are less damaging to the eye but produce light that is often inadequate for concentration at work [71].

Fluorescent lighting may increase UV-related eye diseases by up to $12 \%$ and may cause an additional 3000 cases of cataracts and 7500 cases of pterygia annually in Australia. Thus for Australia alone, there could be at least 10,000 additional cases of eye disease each year.

The evidence suggests that the least hazardous approach to lighting is to use warm-white tubes or incandescent bulbs of lower color temperature and longer wavelength light rather than fluorescent lamps. Unfortunately anything other than fluorescent lighting is considered inadequate for many workplaces and in the home.

It is recommended that UV filters become a required standard, and that lamp manufacturers should not allow current levels of emission of UV light from fluorescent lighting to increase (and should work toward reducing emissions). Further research is also needed to improve lighting from artificial sources [71].

\section{Airtight buildings}

Air pollution is likely to be a factor leading to an increase in morbidity and mortality due to the effects of climate change in Australia [18] and there is a considerable amount of research indicating causation between general air pollution and a range of diseases [73] particularly chronic obstructive pulmonary disease resulting from traffic pollution [74]. We spend over $70 \%$ of our time in buildings [75] with little awareness as to how indoor environments may adversely affect public health, such as exposure to known factors of dust mites, endotoxins, mould passive smoke inhalation [75]. In the drive to make buildings more energy efficient which includes making them better sealed against draughts and unwanted air infiltration, energy efficient buildings need to be provided with adequate ventilation to avoid concentrations of indoor pollutants such as radon [15].

Radon a naturally occurring gas emitted from the ground and a known carcinogen, exposure to which increases the risk of lung cancer $[76,77]$. Since air pollution by radon is already ubiquitous [77-80], as governments in the developed world mandate for better insulated and sealed houses as an energy saving measure to mitigate the effects of climate change, levels of radon in homes and workplaces could increase significantly, exposing occupants to additional health risks. Airtight buildings lead to reduced ventilation, by way of reduced air circulation and air changes within living areas. The drive for energy efficient buildings must not be at the expense of indoor air quality.

Prudent radon-mitigation practice requires implementa- 
tion since the extent of increased radon-induced lung cancers due to energy efficiency measures for climate change are as yet unknown [81].

\section{Air conditioning}

In order to mitigate against heatwaves air conditioning is used in buildings; by those who can afford it. Their use generates more heat into "island" microclimate and contributes more to greenhouse gases due to increased electricity generation [44]. The extent of increased demand in energy for cooling in summer can be such that it exceeds that of energy demand for heating in winter, which has been documented in North America, Europe and Asia [82]. In the aftermath of the 9.0 magnitude earthquake in March 2011 off the coast of Sendai, Japan, in the summer of 2013 the Japanese Government reconvened an energy conservation campaign in order to reduce peak energy demand when most air conditioning units are operating for cooling interiors [83].

A downside of air conditioning (or humidifiers) is the potential for contracting Legionnaires disease. It is an accepted public health risk which is relatively easy to link with air conditioning systems [84]. The bacteria (mostly Legionella pneumophila) remain viable outside the body for relatively long periods and up to a year in fresh water streams where it is ubiquitous [85] and in air conditioning systems and domestic water supplies (above $20^{\circ} \mathrm{C}$ ). The disease is not highly infectious (from person to person) but inhalation from aerosols is the usual source of infection [84]. A 2011-2012 review of the incidence of Legionella infection was carried out in Israel resulting in some infections and deaths in children attributed to exposure to infected humidifiers [86] and also a confirmed death [87].

The key in overcoming the chances of Legionnella infection is to ensure that only sterile or chilled pre-boiled water is used in such home devices, along with daily changes of water and weekly cleaning [86].

\section{Flood mitigation-Detention pond and wetlands}

The worst effects of flash floods can be reduced by creating water detention ponds and wetlands which act as temporary storage and buffer downstream cities from peak flows of flooding. Control measures may include improved climate monitoring and early warning systems, construction of flood embankments, more resistant buildings and infrastructure and community shelters [88].

The Bangladesh government built concrete storm-proof shelters on high pillars as a refuge for villages during storms and flooding but in a 1991 event (Cyclone Bob) not many locals could reach the structures and of those who survived found themselves marooned for days or weeks following the storm [24]. 138,000 people died [88]. Storm surges caused by cyclones normally cause considerable death and damage as they have reached 10 metres in height and led to extensive inland flooding in Bangladesh [26].
Much has been said in relation to risks to populations mostly affecting the poor, whether it be developing countries or poor people at the individual level. Disasters often hit hardest against those on the political periphery, which may include remote rural regions and informal squatter settlements [88]. Many such developments are likely to comprise extra-legal capital and be based on illegal poor construction standards [89].

Hurricane Katrina in 2005 in Louisiana was a catastrophic weather event which displaced 250,000 people and was the costliest and most destructive hurricane ever to hit the US [47]. It happened in one of the world's wealthiest nations, but did the response occur commensurate with that wealth and is future-proofing taking place, considering that New Orleans is situated below sea level?"Fatalism is a cross-cultural human trait" [24]. "Urban areas are still likely to concentrate unhealthy environmental exposures" even when urban environments are modified to mitigate the effects of climate change [47].

In order to reduce impervious surfaces (and hence runoff intensity) in more densely built cities several commentators have suggested the use of green roofs [33].

\section{On-site rain water storage tanks}

Water is becoming an increasingly scarce resource, thus adaptation to climate change is leading to increased use of on-site rainwater tanks $[\mathbf{9 0 , 9 1 ]}$. In Australia, for example, the use of tanks is relatively common and some state governments, local governments and NGOs are already subsidising the purchase of additional rainwater tanks [92-96].

While there are a number of reports of disease outbreaks due to microbiological pathogens [96] which is well researched, there is a pressing need to consider vector-borne diseases such as dengue fever, as this is likely to be a factor leading to an increase in morbidity and mortality due to the effects of climate change in Australia. The widespread installation of domestic water tanks in urban areas could exacerbate the situation due to providing increased breeding habitat for mosquitoes [18].

The distribution of the mosquito species which transmits dengue fever, Ae. Aegypti, is more determined by human activity than by climate, in that human adaptation to climate change through the installation of water storage tanks may pose a greater risk to the Australian population than would the direct effects of climate change [97].

\section{Copper in building water supplies}

The likelihood of greater concentrations of dissolved copper in stored water supplies justifies further consideration and research. Increasing atmospheric $\mathrm{CO}_{2}$ levels, a direct result of the burning of fossil fuels (i.e., climate change), may lower the $\mathrm{pH}$ of ambient dry air and hence lead to such water that is presently prone to being relatively acidic (with a low $\mathrm{pH}$ ), to become more acidic when stored in on-site tanks. $\mathrm{pH}$ controls are not normally applied to on-site tank water, in contrast to some town water supplies and the more acidic 
water may be more likely to cause corrosion of copper water pipes in buildings. A large proportion of existing building stock in developed countries is likely to have copper water supply pipes [98].

While copper is both an essential nutrient and a drinking water contaminant, too little leads to a deficiency and too much may cause toxicity [99-103]. The health risks associated with copper exposure through drinking water are well described, but the exposure-risk scenario may change in future decades due to climate change.

A climate change-related scenario of increased use of rainwater tanks for private water supplies and increased levels of atmospheric $\mathrm{CO}_{2}$ combined with the use of copper reticulation pipes should therefore be reviewed in light of the possible ramifications arising.

The risk of increased acidity of water from copper pipes can be reduced by using concrete storage tanks (rather than those made from plastic or corrugated steel) to counter low $\mathrm{pH}$ levels of the stored water, and using other than copper water supply pipes to the taps in buildings [98].

\section{Re-use of waste water}

Water shortages are presently occurring in some parts of the world and the recycling of waste water is seen as conserving the resource as rainfall patterns, flood cycles and droughts further change in the future [104].

Treated wastewater has several uses, apart from agricultural irrigation, such as aquaculture, industrial processes, groundwater recharge, and even for potable water supply after extended treatment. There are membrane wastewater plants producing potable water in several countries including Japan and the US, and the UNEP was introducing the required technology to provide rural communities in southern Iraq with safe drinking water from waste water [104]. In Beijing, China, there were around 1,000 decentralized wastewater reuse systems in 2010 and their numbers are increasing, which are used mostly for spray irrigation [105].

The use of treated wastewater is implemented in Shinjuku, a suburb of Tokyo where a dual distribution system has been adopted. Sand-filtered water from the Ochiai Municipal Wastewater Treatment Plant is chlorinated and used as toilet-flushing water in 25 high-rise business premises. This has been operating since 1984 and it is supplying up to $8,000 \mathrm{~m}^{3}$ of water daily [104]. Treated wastewater is also being used as an environmental enhancement, augmenting natural/artificial streams, fountains, and ponds. The reuse of wastewater is an integral part of policy for Australia's water resource management with a scheme under consideration of infiltrating a potable aquifer with treated wastewater to secure Perth's drinking water supplies into the future [106].

Although reuse of wastewater has always been used in some countries, there is a lack of national institutions responsible for urban and rural sanitation in $10 \%$ of countries in Asia, Africa and the Americas and there is a need to review exist- ing relevant institutions to undertake wastewater recycling projects in those countries [104]. One of the biggest challenges ahead for those countries whose wastewater reuse practices are lagging is to ensure that highly trained engineers and technologists are used and are able to influence public policy to provide the best environmental and public health outcomes. There needs to be transparency in methodology employed in monitoring and outcomes of health effects research which should be effectively communicated to the public [107]. However, this is unlikely to happen in many countries in the world.

A further challenge facing the viable and safe reuse of wastewater is the increasing problem of identifying and being able to remove chemicals, hormones and endocrine-disrupting chemicals (EDCs), [13] some of which are known to be associated with disease and disability with environmental exposures to low doses $[108,109]$. The long-term effects of exposure to low levels of chemicals are not well understood [107].

Water-sensitive cities will need an integrated strategy to innovate methods of water capture, treatment and re-use [110] but further investigation is required relating to adverse health and environmental effects [18]. We advocate further research in relation to conventional testing of wastewater, also including chemicals, hormones and EDCs and the potential for disease in a climate change/water shortage/burgeoning world population regime of the future.

\section{Discussion and conclusion}

This review illustrates but a few of the factors of the built environment which are expected to increase health risks while adaptations to climate change are carried out along with the simultaneous burgeoning of the world's population into increasingly concentrated areas. There are likely to be many unintended consequences which produce new vulnerabilities. It is generally accepted that the poor and others who are less able to adapt will suffer the most, and there is the potential for violence [65]. The poor often face greater risk because their homes offer the least protection and the most vulnerable to die in natural disasters are women, elderly people and children [26].

The most crucial disaster planning element and intervention post-disaster to have in place is provision of potable water followed by the provision of food, health care and other necessary relief services [26].

Adaptation is important in relation to developing new technologies, reducing dependence on fossil fuels, obtaining more value out of fewer resources and making our buildings more energy-efficient, but we must be cognisant of the foreseen and unintended adverse consequences and deal with those as we progress into a new low carbon consumption future. This should include such things as "bidirectional relations of causality, feedback loops, and tensions between objectives" [13].

Due to the fact that morbidity and mortality from en- 
vironmental threats is already happening to marginalized populations around the world, the need to act is now in catch-up mode so that current and future adaptations to climate change do not impose a further health burden on an increasing number of people.

\section{Competing interests}

The author declares that he has no competing interests.

Publication history

Editor: Mahmoud Hewehy, Ain-Shams University, Egypt.

Received: 30-Dec-2015 Final Revised: 28-Jan-2016

Accepted: 10-Feb-2016 Published: 23-Feb-2016

\section{References}

1. Adger WN, Arnell NW and Tompkins EL. Successful adaptation to climate change across scales. Global Environmental Change. 2005; 15:77-86. 2005. | Article

2. Younger M, Morrow-Almeida HR, Vindigni SM and Dannenberg AL. The built environment, climate change, and health: opportunities for cobenefits. Am J Prev Med. 2008; 35:517-26. | Article | PubMed

3. NASA. How do we know the climate is changing? 2015. | Website

4. Day C. Ethical building in the everyday environment: A multilayer approach to building and place design. Chapter 10 in: Ethics and the built environment. W Fox, editor. Routledge. 2000. I Pdf

5. Levine $M$ and Urge-Vorsatz $D$ et al. Residential and commercial buildings. Climate Change 2007: Chapter 6. Working Group III: Mitigation of Climate Change. IPCC Fourth Assessment Report: Climate Change. 2007. I Article

6. Brown MR, Southworth F and Stovall TK. Towards a climate-friendly built environment. Arlington VA, Pew Center on Global Climate Change. 2005. I Pdf

7. Brown M and Southworth F. Mitigating Climate Change Through Green Buildings and Smart Growth. Georgia Tech Ivan Allen College School of Public Policy. 2006; 23. I Pdf

8. US Department of Energy. Buildings energy data book. Oak Ridge TN: $D$ \& R International Ltd. 2011. | Pdf

9. Curwell $S$ and Cooper I. The implications of urban sustainability Building Research and Information. 1998; 26:17-28. | Article

10. World Health Organization. Environmental burden of disease associated with inadequate housing: A method guide to the quantification of health effects of selected housing risks in the WHO European region. 2011. I Pdf

11. Krieger $\mathrm{J}$ and Higgins DL. Housing and health: time again for public health action. Am J Public Health. 2002; 92:758-68. | PubMed Abstract I PubMed FullText

12. Howden-Chapman P. Housing standards: a glossary of housing and health. J Epidemiol Community Health. 2004; 58:162-8. | Article | PubMed Abstract | PubMed FullText

13. Rydin Y, Bleahu A, Davies M, Davila JD, Friel S, De Grandis G, Groce N, Hallal PC, Hamilton I, Howden-Chapman P, Lai KM, Lim CJ, Martins J, Osrin D, Ridley I, Scott I, Taylor M, Wilkinson P and Wilson J. Shaping cities for health: complexity and the planning of urban environments in the 21st century. Lancet. 2012; 379:2079-108. I Article I PubMed Abstract | PubMed FullText

14. Brijnath B, McMichael AJ and Butler CD. Rio+20: Don't forget health in sustainability talks. Nature. 2012; 486:191. | Article | PubMed

15. Haines $A$ and Dora $C$. How the low carbon economy can improve health. BMJ. 2012; 344:e1018. | Article | PubMed

16. Vale $B$ and Vale R. Urban design: The challenge of sustainability. Journal of Urban Design. 1996; 1:141-2. | Article

17. While $A$ and Whitehead M. Cities, urbanisation and climate change.
Urban Studies. 2013; 50:1325-1331. | Article

18. Bambrick HJ, Capon AG, Barnett GB, Beaty RM and Burton AJ. Climate change and health in the urban environment: adaptation opportunities in Australian cities. Asia Pac J Public Health. 2011; 23:67S-79. | Article | PubMed

19. Keim ME. Building human resilience: the role of public health preparedness and response as an adaptation to climate change. Am J Prev Med. 2008; 35:508-16. I Article I PubMed

20. Business Standard. $\mathbf{1 1 0}$ killed, $\mathbf{3 0 0 , 0 0 0}$ affected due to heavy rains in Pakistan. 2013. | Website

21. World Health Organization. Floods: Climate change and adaptation strategies for human health. Report on a WHO meeting London, UK. 2002. I Website

22. Ministry for the Environment. Preparing for future flooding-A guide for local government in New Zealand. Publication ref, ME 1012. New Zealand Government. 2010. I Pdf

23. Livescience. Coastal flooding damage: \$1 trillion a year by 2050. 2013. | Website

24. De Blij H. The Power of Place. Oxford University Press. 2009. | Book

25. Brouwer R, Akter S, Brander L and Haque E. Socioeconomic vulnerability and adaptation to environmental risk: a case study of climate change and flooding in Bangladesh. Risk Anal. 2007; 27:31326. | Article | PubMed

26. Cash RA, Halder SR, Husain M, Islam MS, Mallick FH, May MA, Rahman $\mathrm{M}$ and Rahman MA. Reducing the health effect of natural hazards in Bangladesh. Lancet. 2013; 382:2094-103. I Article I PubMed

27. Haines $A$. Climate change and health: strengthening the evidence base for policy. Am J Prev Med. 2008; 35:411-3. I Article I PubMed

28. IRIN. Bangladesh: Dhaka's shrinking wetlands raise disaster risks. Humanitarian News and Analysis. A service of the UN Office for the Coordination of Humanitarian Affairs. 2012. I Website

29. Nicholls RJ, Hanson S, Herweijer C, Patmore N, Hallegatte S, CorfeeMorlot J, Château J and Muir-Wood R. Ranking port cities with high exposure and vulnerability to climate extremes: Exposure estimates. OECD Environment. 2008; 1. I Article

30. Epstein PR. Climate change and human health. N Engl J Med. 2005; 353:1433-6. | Article | PubMed

31. Shukla J, Nobre $C$ and Sellers P. Amazon deforestation and climate change. Science. 1990; 247:1322-5. | Article I PubMed

32. Livescience. Deforestation: Facts, causes \& effects. 2015. | Website

33. Mentens J, Raes D and Hermy M. Green roofs as a tool for solving the rainwater runoff problem in the urbanized $21^{\text {st }}$ century? Landscape and Urban Planning. 2006; 77:217-226. | Article

34. NIWA. Cyclone Bola still making its mark after $\mathbf{2 1}$ years. Twenty one years after New Zealand's most devastating cyclone struck the country, the effects of Cyclone Bola are still with the East Coast of the North Island, New Zealand. 2009. I Website

35. Food \& Agricultural Organisation. Effects of drought on farm production and livestock holdings. FAO Corporate Document Repository. 2013. I Website

36. Kamber G, McDonald C and Price G. Drying out: Investigating the economic effects of drought in New Zealand. Reserve Bank of New Zealand Analytical Notes, AN 2013/02. 2013.

37. KPMG. Drought worst in nearly $\mathbf{7 0}$ years. 2013. | Website

38. McMichael A. Heatwaves, mozzies, dengue and droughts - how climate change threatens our health. The Conversation, 24/03/11. 2011. | Article

39. World Health Organization. Improving public health responses to extreme weather/heat-waves. EuroHEAT. 2009. | Pdf

40. Nairn J and Fawcett R. Defining heatwaves: heatwave defined as a heat-impact event servicing all community and business sectors in Australia. CAWCR Technical Report no. 060, Bureau of Meteorology, Australian Government. 2013. I Pdf

41. Victoria Government. A guide to building in Victoria after the 
bushfires. Building Commission. 2009. I $\underline{\text { Pdf }}$

42. Horton R. Australia leads on climate and health. The Lancet. 2015; 386:1520. | Pdf

43. Frumkin $\mathrm{H}$. Climate change and public health. Testimony of Select Committee on Energy Independence and Global Warming, US House of Representatives. 2008. | Article

44. Grimmond S. Urbanization and global environmental change: local effects of urban warming. Cities and global environmental change. 173:2007; 83-88. | Article

45. Oke TR. Boundary Layer Climates, Second Edition. Routledge. 1992. | Book

46. Patz JA. Global climate change and ozone depletion. In 53. Environmental health hazards. Kjellstom, T., Yassi, A., Editors, Encyclopedia of occupational health and safety, International Labor Organization, Geneva. 2011. I Website

47. Hess JJ, Malilay JN and Parkinson AJ. Climate change: the importance of place. Am J Prev Med. 2008; 35:468-78. | Article | PubMed

48. Diamond J. Collapse-How societies choose to fail or succeed. Penguin Books. 2005. I Pdf

49. Crowley $\mathrm{K}$ and Elliott JR. Earthquake disasters and resilience in the global North: lessons from New Zealand and Japan. The Geographical Journal. 2011; 1475-4959. | Article

50. Dilley M, Chen R, Deichman U, Lerner-Lam AL and Arnold M. Natural disaster hotspots: A global analysis. World Bank, Washington DC. 2005.

51. Chen XL, Zhou Q, Ran H and Dong R. Earthquake-triggered landslides in southwest China. Natural Hazards and Earth System Sciences. 2012; 12:351-363. I Pdf

52. Peek-Asa C, Ramirez M, Seligson $H$ and Shoaf K. Seismic, structural, and individual factors associated with earthquake related injury. Inj Prev. 2003; 9:62-6. | Article | PubMed Abstract | PubMed FullText

53. Ramirez $M$ and Peek-Asa C. Epidemiology of traumatic injuries from earthquakes. Epidemiol Rev. 2005; 27:47-55. | Article | PubMed

54. Naghii MR. Public health impact and medical consequences of earthquakes. Rev Panam Salud Publica. 2005; 18:216-21. | Article | PubMed

55. Bartels SA and VanRooyen MJ. Medical complications associated with earthquakes. Lancet. 2012; 379:748-57. | Article | PubMed

56. Walls KL and Mujoo I. Gujarat Earthquake, January 2001-Lessons to be Learnt. New Zealand Society for Earthquake Engineering Conference, Napier, New Zealand. 2002. I Pdf

57. Peleg K, Reuveni $\mathrm{H}$ and Stein M. Earthquake disasters--lessons to be learned. Isr Med Assoc J. 2002; 4:361-5. | Article | PubMed

58. Yayong W. Revision of seismic design codes corresponding to building damages in the "5.12" Wenchuan earthquake. Earthquake Engineering \& Engineering Vibration. 2010; 9:147-155. | Article

59. Ardagh MW, Richardson SK, Robinson V, Than M, Gee P, Henderson S, Khodaverdi L, McKie J, Robertson G, Schroeder PP and Deely JM. The initial health-system response to the earthquake in Christchurch, New Zealand, in February, 2011. Lancet. 2012; 379:2109-15. | Article I PubMed

60. Standards Association of New Zealand. Code of Practice for General Design and Design Loadings for Buildings. NZS 4203: 1976. | Website

61. Standards Australia/Standards New Zealand. Structural design actionsgeneral principles-Commentary. AS/NZS 1170.0 Supplement 1: 2002. I Pdf

62. Alexander D. What can we do about earthquakes? Towards a systematic approach to seismic risk mitigation. New Zealand Society for Earthquake Engineering Bulletin. 2012; 45. | Pdf

63. Reitherman R. Application of earthquake engineering information in hospital emergency response and recovery. Consortium of Universities for Research in Earthquake Engineering, Richmond, California. 2004. | $\underline{\text { Pdf }}$

64. Walls $\mathrm{HL}$, Walls $\mathrm{KL}$ and Loff $\mathrm{B}$. The regulatory gap in chronic disease prevention: a historical perspective. J Public Health Policy. 2012;
33:89-104. | Article | PubMed

65. Welzer $\mathrm{H}$. Climate wars: Why people will be killed in the $\mathbf{2} \mathbf{1}^{\text {st }}$ Century Polity Press, UK \& USA. 2012.

66. World Health Organization. Our planet, our health, our future. Human health and the Rio Conventions: Biological diversity, climate change and desertification. 2011. | Pdf

67. Kanter J. Europe's ban on old-style bulbs begins. The New York Times. 2009. I Pdf

68. Australian Government. National Strategy on Energy Efficiency. Environment budget overview 2009-10. 2010. I Pdf

69. Public Law No. 110-140 (2007) United States Congress. 2007. | Pdf

70. Australian Government. Tracking to the Kyoto Target 2007: Australia's Greenhouse Emissions Trends 1990 to 2012 and 2020. Department of Climate Change. Canberra, ACT, Australia. 2008. | Pdf

71. Walls $\mathrm{HL}$, Walls $\mathrm{KL}$ and Benke $\mathrm{G}$. Eye disease resulting from increased use of fluorescent lighting as a climate change mitigation strategy. Am J Public Health. 2011; 101:2222-5. | Article | PubMed Abstract | PubMed FullText

72. Wang $L$, Chen $Y, H u$ G and Bidanda R. Can green products survive market competition? 2008. | Website

73. Devi S. New studies cast dark cloud over air pollution. Lancet. 2012; 379:697. | PubMed

74. Andersen ZJ, Hvidberg M, Jensen SS, Ketzel M, Loft S, Sorensen M, Tjonneland A, Overvad K and Raaschou-Nielsen O. Chronic obstructive pulmonary disease and long-term exposure to traffic-related air pollution: a cohort study. Am J Respir Crit Care Med. 2011; 183:455-61. | Article | PubMed

75. Baker M, Keall M, Au EL and Howden-Chapman P. Home is where the heart is--most of the time. NZ Med J. 2007; 120:U2769. | PubMed

76. Lubin $\mathrm{JH}$ and Boice JD, Jr. Lung cancer risk from residential radon: meta-analysis of eight epidemiologic studies. J Nat/ Cancer Inst. 1997; 89:49-57. | Article | PubMed

77. Krewski D, Lubin JH, Zielinski JM, Alavanja M, Catalan VS, Field RW, Klotz JB, Letourneau EG, Lynch CF, Lyon JI, Sandler DP, Schoenberg JB, Steck DJ, Stolwijk JA, Weinberg C and Wilcox HB. Residential radon and risk of lung cancer: a combined analysis of 7 North American casecontrol studies. Epidemiology. 2005; 16:137-45. | Article | PubMed

78. Radford EP. Potential health effects of indoor radon exposure. Environ Health Perspect. 1985; 62:281-7. | PubMed Abstract | PubMed FullText

79. Darby S, Hill D, Auvinen A, Barros-Dios JM, Baysson H, Bochicchio F, Deo H, Falk R, Forastiere F, Hakama M, Heid I, Kreienbrock L, Kreuzer M, Lagarde F, Makelainen I, Muirhead C, Oberaigner W, Pershagen G, Ruano-Ravina A, Ruosteenoja E, Rosario AS, Tirmarche M, Tomasek L, Whitley E, Wichmann HE and Doll R. Radon in homes and risk of lung cancer: collaborative analysis of individual data from 13 European case-control studies. BMJ. 2005; 330:223. | Article | PubMed Abstract I PubMed FullText

80. Ministry of Health. Radiation situation in Japan-Information for health providers. New Zealand. 2011. I Pdf

81. Walls KL, Benke GP and Kingham SP. Potential increased radon exposure due to greater building energy-efficiency for climate change mitigation. Air Quality and Climate Change. 2014; 48. | Article

82. Hadley SW, Ericksen DJ, Hernandez JL, Broniak CT and Blasing TJ. Responses of energy use to climate change: A climate modeling study. Geophysical Research Letters. 2006; 33.

83. JDP. Japan kick offs [sic] power saving campaign for another summer. 2013. | Website

84. Walls KL. Microbiological Aerosols in Drainage Systems. PhD thesis. University of Auckland, New Zealand. 1999. I Pdf

85. Jensen MM, Wright DN and Robison RA. Microbiology for the health sciences. Prentice-Hall International. 1995. I Book

86. Water Quality Research Australia. Health Stream. 2013; 68.

87. Moran-Gilad J, Lazarovitch T, Mentasti M, Harrison T, Weinberger M, Mordish Y, Mor Z, Stocki T, Anis E, Sadik C, Amitai Z and Grotto I. Humidifier-associated paediatric Legionnaires' disease, Israel, 
Kelvin Walls, Journal of Environmental Engineering \& Ecological Science 2016, http://www.hoajonline.com/journals/pdf/2050-1323-5-1.pdf

February 2012. Euro Surveill. 2012; 17:202-93. | Article | PubMed

88. Hannigan J. Disasters without borders-The international politics of natural disasters. Polity. 2012. | Article

89. Walls KL. Diminishing Capital Value of Buildings and Infrastructure in New Zealand. IPENZ Convention, Auckland. 2007. | Article

90. Australian Government. Guidance on use of rainwater tanks. 2004.| $\underline{\text { Pdf }}$

91. Boyle C, Mudd G, Mihelcic JR, Anastas P, Collins T, Culligan P, Edwards M, Gabe J, Gallagher P, Handy S, Kao JJ, Krumdieck S, Lyles LD, Mason I, McDowall R, Pearce A, Riedy C, Russell J, Schnoor JL, Trotz M, Venables R, Zimmerman JB, Fuchs V, Miller S, Page S and Reeder-Emery $K$. Delivering sustainable infrastructure that supports the urban built environment. Environ Sci Technol. 2010; 44:4836-40. | Article | PubMed

92. Victoria Government. Energy Efficiency for Victoria: Action Plan. 2006.

93. Japan for Sustainability. Subsidy Supports Use of Rainwater Tanks in Kobe. 2004. I Article

94. Cornut $\mathrm{P}$, Aubin $\mathrm{D}$, Van Criekingen $\mathrm{M}$, Dubois O, Prevedello C, Dessouroux C and Decroly JM. Public 'Club' and Individual Management of Natural Resources - The case of domestic rainwater tanks in Belgium. Environmental Economic Geography: State of the Art and Prospects. Köln, Germany. 2004. | Pdf

95. Department of Water Affairs and Forestry. DWAF Financial Assistance for Resource Poor Irrigation Farmers Manual on DWAF Financial Assistance. 2004. I Pdf

96. Sinclair M. How safe is rainwater consumption? Public Health Bulletin South Australia. 2007; 4.

97. Beebe NW, Cooper RD, Mottram P and Sweeney AW. Australia's dengue risk driven by human adaptation to climate change. PLoS Negl Trop Dis. 2009; 3:e429. | Article | PubMed Abstract | PubMed FullText

98. Walls KL, Walls HL, Benke $\mathrm{G}$ and McMichael AJ. Ensuring climate change adaptation avoids increased health risks from drinking-water copper exposure. Air Quality and Climate Change. 2014; 48. | Article

99. Knobeloch L, Ziarnik M, Howard J, Theis B, Farmer D, Anderson $\mathrm{H}$ and Proctor M. Gastrointestinal upsets associated with ingestion of copper-contaminated water. Environ Health Perspect. 1994; 102:95861. | PubMed Abstract | PubMed FullText

100. Hunter Water Laboratories. 'Blue Water' and Corrosion of Copper Tubes in Hunter Water Corporation Water. Australia. 1997.

101. Fitzgerald DJ. Safety guidelines for copper in water. Am J Clin Nutr. 1998; 67:1098S-1102S. | Article | PubMed

102. World Health Organization. Copper in Drinking-water-Background document for development of WHO Guidelines for Drinking-water Quality. 2004. | Pdf

103. Uauy $R$, Maass A and Araya M. Estimating risk from copper excess in human populations. Am J Clin Nutr. 2008; 88:867S-71S. | Article | PubMed

104. UNEP. Water and Wastewater reuse: An Environmentally Sound Approach for Sustainable Urban Water Management. 2005. | Pdf

105. Liang $X$ and van Dijk MP. Financial and economic feasibility of decentralized wastewater reuse systems in Beijing. Water Sci Technol. 2010; 61:1965-73. | Article | PubMed

106. Browne AL, Leviston Z, Greenhill MP, Nancarrow BE, Tucker DI and Porter NB. Structuring dimensions of risk: Technical and community perceptions of risk in the reuse of wastewater for irrigation and indirect potable supply. National Research Flagships, CSIRO, Australia. 2007. I Pdf

107. O'Toole J, Leder K and Sinclair M. Recycled water and human health effects. Aust Fam Physician. 2007; 36:998-1000. | Article | PubMed

108. Helland J. Endocrine disrupters as emerging contaminants in wastewater. Information Brief. Minnesota House of Representatives Research Department. 2006; 651-296-5039. I Pdf

109. Vandenberg LN, Colborn T, Hayes TB, Heindel JJ, Jacobs DR, Jr., Lee DH, Shioda T, Soto AM, vom Saal FS, Welshons WV, Zoeller RT and Myers JP. Hormones and endocrine-disrupting chemicals: low-dose effects and nonmonotonic dose responses. Endocr Rev. 2012; 33:378-455. | Article | PubMed Abstract | PubMed FullText

110. Brown $\mathrm{R}$, Keath $\mathrm{N}$ and Wong $\mathrm{T}$. Transitioning to water sensitive cities: Historical current and future transition states. Paper presented at $11^{\text {th }}$ International Conference on Urban Drainage, Edinburgh, Scotland. 2008. | Pdf

\section{Citation:}

Walls K. Ensuring adaptation to climate change does not increase health risks from the built environment. J Environ Eng Ecol Sci. 2016; 5:1.

http://dx.doi.org/10.7243/2050-1323-5-1 